\title{
JEWISH MODERN LAW AND LEGALISM IN A GLOBAL AGE: THE CASE OF RABBI JOSEPH KARO
}

\author{
RONI WEINSTEIN
}

The Rothberg International School, The Hebrew University, Jerusalem

E-mail: Roni.Weinstein@mail.huji.ac.il

\begin{abstract}
During the late sixteenth and early seventeenth centuries, Rabbi Joseph Karo composed two major Jewish codes of law: the Beit Yosef, and its abridged version, Sulchan 'Aruch. Though several centuries of legal discussion and scholarship have passed since their publication, these double codes of law were never superseded. This codification project defined the axial place of law in Jewish tradition. I argue that it responded to changes in legal processes and the enforcement of law that simultaneously transformed early modern Europe and the Ottoman world. Transcontinentally connected changes in political institutions - the formation of a centralized Islamic empire in the Ottoman case, and the formation of centralized states in Europe-dramatically redefined the role of law and legal codification in the forging of state power and community identities. The resultant belief among Sephardi rabbis, including Karo, that changes in Jewish legal tradition were now needed, prompted a redefinition of Jewish legal culture, whereby law (a gradually centralized conception of it) began to be seen as the foundation of Jewish religious heritage and ethnic identity. Despite the absence of state backing, early modern transformations in Jewish law were thus part of comparable changes taking place in the European and Islamic legal worlds.
\end{abstract}

In medieval Jewish life, legal heritage maintained a privileged position within the rabbinic milieu, considered by the latter and by others to be the incarnation of religious tradition and past inheritance. For Jews, life as an ethnic and religious minority enhanced the importance of legal-Talmudic studies in maintaining the integrity of a marginalized (and often threatened) community, through its implementation in legal mechanisms as well as in public or community life. This article argues that the changing role of legality within Jewish life during the early modern period indicated an overall radical transformation in this milieu. This transformation was truly global in conceptual scope, and occurred in response to a rapidly changing world characterized by powerful 
emerging states in Europe (and its overseas colonies) as well as in coeval Islamic empires.

Jewish history, all along its various phases and in different historical settings, has consistently resonated with two prominent features: dispersion and awareness of the centrality of the Diaspora. ${ }^{1}$ The Bible tells of the passage from the land of Canaan to Pharaonic Egypt-where the people of Israel turned into a nationand back to the Promised Land. Later in the First and Second Temple Periods, alongside the Jewish population in the Holy Land, large communities prospered either in the east (Babylon, today Iraq), or along the Mediterranean basin. With the rise of Islam, the dominant position of Jewish Babylonian scholars (geonim in Hebrew) and leaders across the Holy Land and the rest of Jewish Diaspora became increasingly conspicuous. During the Middle Ages, the scope of Jewish settlements advanced beyond the Mediterranean toward northern Europe (the French Ashkenazi tradition), as well as maintaining massive communities in Spain (the Sephardi tradition).

The early modern period, however, marked a shift in this domain for two major reasons. ${ }^{2}$ The first one was unprecedented geographical extension to places unknown in classical Jewish culture, such as the new Ashkenazi center in Eastern and Central Europe (mainly Poland) and Russian territories, ${ }^{3}$ or the vast Sephardi diaspora in northern Europe, and, following the discovery of the "New World" and Iberian colonialist expansion, the establishment of Jewish or Conversos settlements in North and South America, as well as in Southeast Asia. ${ }^{4}$ The second innovative element in Jewish exile was the weaving of a faster and more extensive network of physical and intellectual communication between various Jewish diasporas. ${ }^{5}$ The print revolution was a case in point; several printing centers produced the major components of the Jewish Canon-the Bible and its classical commentaries; the Babylonian Talmud and its leading exegetical additions; Sefer HaZohar or the "Book of Splendor," the major mystical corpus of the medieval period; and prayer books, liturgies, ethical tracts-and quickly

Yitzhak F. Baer, Galut (Exile), trans. Robert Warshow (Lanham 1988).

2 Jewish history in the early modern period is discussed in David B. Ruderman, Early Modern Jewry: A New Cultural History (Princeton, 2010); Dean Ph. Bell, Jews in the Early Modern World (Lanham, 2008).

3 Israel Bartal and Israel Gutman, eds., Kium va-Shever: Yehudei Polin leDoroteihem (The Broken Chain: Polish Jewry through the Ages), 2 vols. (Jerusalem, 1997); Bartal and Gutman, eds., MiYemei Kedem 'ad Ha'Et HaChadashah HaMukdemet (From Ancient Times to the Early Modern Age), vol. 1 of Alexander Kulik, gen. ed., Toldot Yehudei Russia (History of the Jews in Russia) (Jerusalem, 2010).

$4 \quad$ Nathan Wachtel, La foi du souvenir: Labyrinthes marranes (Paris, 2001).

5 Sophia Menache, ed., Communication in the Jewish Diaspora: The Pre-modern World (Leiden,'1996). 
disseminated them among the entire Jewish population. Print and circulation certainly led to increasing standardization and unification of classical texts. This was accompanied by the formation of a "Jewish Republic of Letters" communicating along vast territorial zones, crossing the religious boundaries of Christian Europe (both Protestant and Catholic), the Ottoman Empire, and the Arab world. In short, Jewish history during the early modern world entered a new and global phase, to be analyzed as a further component of global history or connected history. ${ }^{6}$

As a corollary of this process, the local basis of Jewish life was increasingly overtaken by a larger cultural and political horizon, responding to the immense political structures evolving generally in Europe and particularly in the Islamic world: centralized states, colonial empires in Europe, the massive Ottoman Empire. The medieval heritage of community organization and reference to local religious authorities that had been unquestionably dominant in the Jewish milieu for almost a millennium was becoming less relevant. It was characterized by fragmentary "ethnic" units within the Jewish Diaspora, such as Sephardi, Portuguese, Ashkenazi, French, Provençal, Italian, Byzantine, North Africans (Maghreb), Kurdish, Yemenite, and Musta'arab in the area of Bilad a-Sham. Even within each unit, there were important subdivisions; the Sephardi, for instance, comprised Catalans and people of Navarre, Castile, and elsewhere. While these traditions would continue to function and prosper in the coming centuries, the local components would undergo processes of unification and standardization. I wish to discuss one aspect in these significant changes: the religious law (Halakhah, in Hebrew) in particular, and legality in general.

Among the various Jewish diasporas there was one especially benefiting from the opportunities of globalism: the Iberian Jews. ${ }^{7}$ In the sixteenth and early seventeenth centuries was a golden century (siglo de oro) not only for the Spanish and Portuguese empires, but for the Jews expelled from these places and for the remaining Conversos as well. The Jewish Spanish communities, especially those in Castile, had been the leading diaspora-demographically, economically, and politically—all through the Middle Ages. They were governed by a tough and centralistic ruling elite that had firm political connections with Spanish kings, that had political power in governing Jewish communities, and that had elevated

6 On the early modern global perspective see, for instance, Jack Goldstone, Why Europe? The Rise of the West: World History 1500-1850 (Boston, 2009). On the Jewish context in a global world see Roni Weinstein, "Hagut Yehudit beReshit ha'Et haChadashah" (Early Modern Jewish Thought: Main Currents), in Joseph Mali, ed., Historia shel haRa'ayonot (History of Ideas), vol. 2, The Early Modern Period (Jerusalem: forthcoming).

7 Roni Weinstein, "Catholic Traditions in Safed Kabbalah: Sephardim and Conversos," in Weinstein, Kabbalah and Jewish Modernity (Oxford and Portland, 2016), 142-65. 
cultural heritage (Jewish as well as Catholic Spanish, and some components of Muslim heritage, dating back to the pre-Reconquista period). It was no coincidence that the religious life of all Castilian Jews was ruled by a centralized official Rab de la corte, a rabbi nominated by the king's court, and authorized to enforce his legal and religious decisions all over Castile. In Ashkenaz/Germany or in Italy, any attempts to establish a similar institution encountered firm opposition and were rejected out of hand. ${ }^{8}$ Iberian Jews considered themselves superior to other Jewish traditions, due to their particular cultural and political heritage: both Jewish and Spanish. Most of them regarded the Conversos-those who converted to Catholicism but maintained close contact with their former families - as a component of the Jewish Iberian collective, a fact that further added to their unique cultural portrayal. They persistently manifested their self-imposed image as leaders and superiors in their encounters with other Jewish communities along the Mediterranean basin, following the double expulsion from Spain (1492) and Portugal (1497). The Iberian diaspora benefited particularly from adopting a sense of modernity (conversing on baroque literature, theater, political theories, new economic conceptions, the role of modern legality) and engaging in international networks of commerce, political connections, and espionage, and from their familiarity with several languages. ${ }^{9}$ The expulsion was initially accompanied by severe collective trauma, as might be obvious, but it was later mitigated by the fact that the refugees could eventually settle in another prospering and expanding place: the Ottoman Empire. Here they integrated as an additional religious minority and became well acquainted with Sunni traditions and with Ottoman political and cultural patterns. ${ }^{10}$ During the early modern period, the Sephardi diaspora extended over vast territories along the "New World," northern Europe (the leading community being in Amsterdam), and the Mediterranean basin, bridging the religious gaps between Europe and the Ottomans. The increasing military and political antagonism between Charles V and Sultan Süleiman, as well as the competing apocalyptic and messianic visions of both, ${ }^{11}$ did not prevent Jews living both in European cities like Amsterdam, or

8 Mordechai Breuer, "HaShmikhah haAskenazit" (The Ashkenazi Shemikha), Zion 33/1-2 (1968), 15-46, at 28-31.

9 Francesca Trivellato, The Familiarity of Strangers: The Sephardic Diaspora, Livorno, and Cross-cultural Trade in the Early Modern Period (New Haven, 2009).

10 Yaron Ben-Naeh, Jews in the Realm of the Sultans: Ottoman Jewish Society in the Seventeenth Century (Tübingen, 2008).

$11 \quad$ Cornell H. Fleischer, "The Lawgiver as Messiah: The Making of the Imperial Image in the Reign of Süleymân," in Gilles Veinstein, ed., Soliman le Magnifique et son temps (Paris, 1992), 159-177; Tijana Krstic, Contested Conversions to Islam: Narratives of Religious Change and Communal Politics in the Early Modern Ottoman Empire (Stanford, 2011), 76-7, 80-84, $167-72$. 
in Italy, and in important Ottoman cities such as Edirne, Bursa, Salonika, and Istanbul, from maintaining cultural and economic channels of communication, crossing over religious and political borders. It is therefore highly pertinent to contextualize the Jewish ecumene in the global processes of change taking place during the early modern period, especially the sixteenth and early seventeenth centuries. Across this wide planet-spanning geographical extent ${ }^{12}$ — stretching from Western Europe, the Ottoman Empire, the Safavid and Mughal kingdoms, and further east - the Ottomans evidently played a crucial role in the Jewish Diaspora, and in its process of restructuring and adapting the main cultural traits toward modernity. Two illustrations would be sufficient to demonstrate the shifting center of gravity from Europe to the Ottoman Empire. During the seventeenth century, the officials of Istanbul organized the raising of funds and their transference for the Jewish poor of the Holy Land. ${ }^{13}$ This activity required the cooperation of an international network stationed along various Jewish communities in Western Europe, partly in Eastern Europe, in Italy, North Africa, and various Ottoman cities, and the use of a credit system. Surprisingly, the heart of this complex operation was neither Amsterdam, with its prosperous Sephardi community and strong connections to international trade and the stock market, nor Venice, a center of Mediterranean commerce, but the community located in the capital city of the Ottoman Empire. ${ }^{14}$ Significantly, officials in Istanbul even discarded the traditional method of allocating charity, i.e. each diaspora taking care of its own poor people, and organized it on a more general basis. This specifically underlined the "global" or "pan-Judaic" perspective that they deliberately adopted, signaling the presence of the Jewish collective as a unified body, regardless of internal classifications. The second incident indicating Ottoman centrality in the Jewish early modern context was that of the messianic movement of Shabbtai Zvi, who eventually converted to Islam. ${ }^{15}$ Prior to his conversion, apocalyptic expectations had arisen all over the Jewish world, from Yemen and Kurdistan to Maghreb and Amsterdam. The movement progressed

12 Goldstone, Why Europe?

13 Matthias B. Lehmann, Emissaries from the Holy Land: The Sephardic Diaspora and the Practice of Pan-Judaism in the Eighteenth Century (Stanford, 2014).

14 On the special place that Istanbul occupied see Çiğdem Kafescioğlu, Constantinopolis/Istanbul: Cultural Encounters, Imperial Vision, and the Construction of Ottoman Capital (Philadelphia, 2009); Edhem Eldem, Daniel Goffman, and Bruce Masters eds., The Ottoman City between East and West: Aleppo, Izmir, and Istanbul (Cambridge, 1999).

15 Cengiz Şişman, The Burden of Silence: Sabbatai Sevi and the Evolution of the OttomanTurkish Dönmes (New York, 2015). Şişman's book is important because it includes new Ottoman testimonies on the Sabbatean messianic movement. See also Jacob Barnai, Shabta'ut: Hebetim Chevratiim (Sabbateanism: Social Perspectives) (Jerusalem, 200o). 
predominantly in Ottoman cities, and its leading figures were mainly of Sephardi origins.

The changes that emerged in the arena of Jewish law and its concepts of legality were undeniably at the forefront of the passage to modernity, as this article will illustrate, and so was the codification project of Joseph Karo, within its triple encounter of Jewish-European-Ottoman juridical heritage. An important Jewish condition that has to be taken into consideration in this context was the highly limited ability of Jewish communities to enforce their legal norms and the verdicts of legal courts. In the Ottoman context particularly, the limit on their legal autonomy became even more pronounced with respect to other nonMuslim minorities ${ }^{16}$ — such as the Orthodox Greeks or the Armenians, who relied on political powers beyond the Ottoman Empire. ${ }^{17}$ In this particular respect, there was little difference between communities in Amsterdam, Italian communities in major cities, or the Ottoman Empire-mainly in the Rumeli zone..$^{18}$ Maimonides's insight, made during the Middle Ages_- "We are not powerful enough to enforce religious law"19 — was applicable to the early modern period as well. The nonJewish political authorities, determined to underline their political power and sovereignty, defined the limits of Jewish legal autonomy. These limits obstructed the development of legal heritage that potentially could have been shared by major components of Jewish ecumene. Instead, it encouraged local perspectives and fragmentary loyalties to indigenous rabbis and legal scholars. The Jewish

16 Joseph R. Hacker, "HaOtonomiya haYehudit baImperia haOttomanit: Heikefah uMigbalitehah" (Autonomy in the Ottoman Empire: Its Scope and Limits), in Shmuel Almog, ed., Tmurot baHistoriya haYehudit haChadashah: Kovetz Ma'amarim Shai liShmuel Ettinger (Transition and Change in Modern Jewish History: Essays Presented in Honor of Shmuel Ettinger) (Jerusalem, 1987), 349-88; Ben-Naeh, Jews in the Realm of the Sultans, pp. 236-351.

17 Elif Bayaraktar Tellan, "The Patriarch and the Sultan: The Struggle for Authority and the Quest for Order in the Eighteenth Century Ottoman Empire" (Ph.D. thesis, Bilkent University, Ankara, 2011); Hasan Çolak, "Relations between the Ottoman Central Administration and the Greek Orthodox Patriarchates of Antioch, Jerusalem and Alexandria: 16th-18th Centuries" (Ph.D. thesis, University of Birmingham, Birmingham, 2012).

18 Avraham Grossman and Yosef Kaplan, eds., Kehal Israel: HaShilton haAtzmi haYehudi leDorotav (Kehal Israel: Jewish Self-Rule through the Ages), vol. 2, The Middle Ages and Early Modern Period (Jerusalem, 2004). This volume contains updated research on Jewish communities in various diasporas.

19 This saying is discussed in Yedidya A. Dinari, Chachmei Ashkenaz be-Shilhei YemeiHabeinayim. Darkehem ve-Kitvehem baHalachah (The Rabbis of Germany and Austria at the Close of the Middle Ages: Their Conceptions and Halakha Writings) (Jerusalem, 1984), 124-6. 
communities experienced the benefits as well as the disadvantages of legal pluralism and various juridical instances, competing one against another. ${ }^{20}$

The centrality of law in the Jewish way of life was based on two fundamental principles. The first is the voluntary commitment of individuals: an expression of their undisputed loyalty and sense of belonging to the Jewish collective. The religious elite (rabbis and religious scholars of a post-Talmudic legacy) was given the responsibility of maintaining and developing the legal heritage, but it did not possess any sacral dimensions, different from the rest of the Jewish population. ${ }^{21}$ The second, which was even more crucial, was the previously mentioned factor of "locality" - that is, accepting the authority of only local rabbis, schools of legal erudition (yeshivah in Hebrew), courts of law, or leaders of an entire local diaspora. This localistic tendency eventually evolved into two focal traditions: the Ashkenazi (related to Germany and France of today), and the Sephardialongside others of secondary importance in Byzantine lands, Italy, Provence, or North Africa. This locality, in the context of Jewish history, was hardly exceptional. A wide variety of legal mechanisms and legal norms characterized all religious traditions in the early modern period-pertaining to various ethnic or religious groups, urban or rural areas, corporate groups with substantial legal autonomy (such as professional guilds or religious professions in the Catholic Church), or distinct social groups, such as the warrior caste or peasants, local traditions of provinces passed on orally within the community, or ultimately a basic division between law agglomerations stemming from religious traditions (Canon Law, Sharia) in contradistinction to non-religious or civil law (jus civile, jus comune in the European context, and kanun or kanuname in Ottoman surroundings). In central and big cities, such as Paris and Rome in Europe, or Cairo in Mameluke Egypt (prior to the Ottoman conquest in 1516), several systems of law competed for supremacy. In most cases, one centralized legal system imposed by the state, king, or prince and enforced by one legal mechanism was quite unthinkable. People involved in legal processes were adept at manipulating or maneuvering their cases between various legal options. ${ }^{22}$ Historians of the law in late medieval and early modern Europe noticed the high number of court records lacking any final verdict, due to the fact that contestants began with the formal procedure

20 On pluralism see John Griffiths, "What Is Legal Pluralism," Journal of Legal Pluralism 24 (1986), 1-55.

${ }^{21}$ Mordechai Breuer, Oholei Torah: HaYeshiva, Tavnitah veToldoteia (Oholei Torah (The Tents of Torah: The Yeshiva, Its Structure and History) (Jerusalem, 2003); Robert Bonfil, Rabbis and Jewish Communities in Renaissance Italy, trans. Jonathan Chipman (London," 1993).

22 Daniel L. Smail, The Consumption of Justice: Emotions, Publicity, and Legal Culture in Marseille 1264-1423 (Ithaca and London, 2003). 
but eventually transitioned to other less formal—though no less bindingprocedures, such as conciliatory advice offered by intermediaries and arbitrators, informal negotiation, violence and vengeance, or the common use of community mechanisms of peacemaking. ${ }^{23}$

Lauren Benton in her Law and Colonial Cultures has demonstrated that imperial expansion and the establishment of permanent imperial regimes encountered a challenge of legal plurality of indigenous population and local tradition. ${ }^{24}$ Yet the traditional modes of justice were facing strong pressures of change during the early modern period, again in both European and Ottoman contexts. Law was defined and enforced in a new fashion by political powersthat began to emerge as more potent and centralized-which considered the production, study, and enforcement of law as a fundamental component in their new political-cum-religious essence. In both Christian and Ottoman contexts, processes of establishing larger political units, based on cultural, religious, pedagogic, and certainly political unification and homogenization ran parallel. This process was accompanied by an enforcement of religious obedience as a precondition to participation in the body politic, or to playing a meaningful role in political life. These processes of "confessionalization" characterized all three monotheistic religions during the sixteenth and seventeenth centuries. ${ }^{25}$ This stemmed from the need to restructure basic components of political life as a response to new challenges, such as the geographical expansion and conquests of the Arab world and the establishment of a colonial empire (in the Ottoman context), in tandem with the increasing constitution of

23 Mario Sbriccoli, "Giustizia criminale," in Maurizio Fioravanti, ed., Lo Stato moderno in Europa: Istituzioni e diritto (Firenze, 2005), 163-205. See also Sbriccoli, "Legislation, Justice, and Political Power in Italian Cities, 1200-1400," in Antonio Padoa-Schioppa, ed., Legislation and Justice (Oxford, 1997), 37-55.

24 Lauren Benton, Law and Colonial Cultures: Legal Regimes in World History, 1400-1900 (Cambridge and New York, 2004).

25 For more details see Roni Weinstein, "Safed Kabbalah and Modernity," in Weinstein, Kabbalah and Jewish Modernity, 564-95. On the German Ashkenazi context see Dean P. Bell, "Confessionalization in Early Modern Germany: A Jewish Perspective," in Christopher Ocker, Michael Printy, Peter Starenko, and Peter Wallace, eds., Politics and Reformations: Histories and Reformations. Essays in Honor of Thomas A. Brady Jr. (Leiden and Boston, 2007), 345-72. Confessionalization in the Ottoman context was persuasively discussed by Tijana Krstić, "Illuminated by the Light of Islam and the Glory of the Ottoman Sultanate: Self-Narratives of Conversion to Islam in the Age of Confessionalization," Comparative Studies in Society and History 51/1 (2009), 35-63; Derin Terzioglu, "How to Conceptualize Ottoman Sunnitization: A Historiographical Discussion," Turcica 44 (201213), 301-38; Terzioglu, "Where Ilm-i Hạl Meets Catechism: Islamic Manuals of Religious Instruction in the Ottoman Empire in the Age of Confessionalization," Past and Present 220/1 (2013), 79-114. 
centralized modern states, the discovery of the "New World" and ensuing colonialism, the religious rupture between Catholics and Protestants, recurring economic crisis and popular uprisings, and expanding poverty and vagabondage (in the European context).

A good place to begin is the Ottoman Empire, where most of early modern Jewish communities lived. Islam, much like the Jewish tradition, allocated a central place to religious practices, leaning on detailed juridical traditions, dating back to the time of the Prophet himself, and later expanded by religious scholars ('ulama in Arabic). Various schools of law (madhhabs) competed for supremacy, though each was considered legitimate, despite clear differences in their legal implications. ${ }^{26}$ The Ottomans' policy aimed to decrease such legal diversity in favor of legal homogeneity, controlled by the sultans (especially during the period of Süleiman Kanuni, "the legislator"). To start with, they undertook a strategic move by choosing one of the classical madhhab - the Hanafi schooland practically turning it into the formal law of the empire, evidently at the expense of other schools. ${ }^{27}$ This led to important changes in the establishment of legal mechanism, law enforcement, and a legal guild. Law and justice constituted one of the foundations of common life for all subjects under Ottoman rule, regardless of religious identity. The ideology of the sultanic court claimednot entirely arbitrarily reminding one of the "Roman Peace" (Pax Romana) of late antiquity - that Law (kanun) and Justice (adelet in Turkish) will ensure the security, well-being, and prosperity of all subjects obeying the Ottoman rule and respecting their own limits, either as Muslims or as minority groups. This rhetoric of huzur (peace and prosperity within the Ottoman Empire) spread widely in professional legal literature and historical narratives, and even reached Turkish popular literature. ${ }^{28}$

The centers of learning, especially of legal traditions, were established by the sultans, who carefully controlled the nomination of professors and the curriculum. ${ }^{29}$ During Süleiman's reign, a large number of law codes were

26 On madhhabs and their historical evolvement see Guy Burak, The Second Formation of Islamic Law: The Hanafî School in the Early Modern Ottoman Empire (New York, 2015), $6-13$.

27 Besides the comprehensive discussion in Burak, The Second Formation of Islamic Law, see also Snjezana Buzov, "The Lawgiver and His Lawmaker: The Role of Legal Discourse in the Change of Ottoman Legal Culture" (Ph.D. thesis submitted to the University of Chicago, 2005); Fariba Zarinebaf, Crime and Punishment in Istanbul, 1700-1800 (Berkeley, 2010); Haim Gerber, State, Society, and Law in Islam: Ottoman Law in Comparative Perspective (Albany, 1994).

28 Buzov, "The Lawgiver and His Lawmaker," 170-80.

29 Abdurrahman Atcil, Scholars and Sultans in the Early Modern Ottoman Empire (Cambridge, 2016). 
issued, and their contents reorganized and systematized. Provincial law codes were usually attached to the land survey registers, conducted at first during military occupation (such as in Egypt, Syria, Rumeli) and subsequently on a regular basis. In the 1530s, the famous Şeyhülislam Celalzade Mustafa (d. 1567) collated all previous law codes and prepared a general law code, which was issued in the name of Süleiman. Celalzade's compilation was so prestigious that it continued to be in effect, with few changes, until the early seventeenth century. The growing emphasis on centralization and systematization of the administration complemented the policy of legal canonization. ${ }^{30}$ Süleiman put forward claims for impeccable justice and equity, for universal empire, for being a saint-ruler, the messiah, the Islamic caliph. The organization and systematization of administration and the application of religious law as well as law codes were used to substantiate these claims.

Unlike previous generations, legal experts now depended on the state for their promotion and prestige. They were employees of the sultanic court, and increasingly identified with Ottoman culture, rather than with Islamic tradition at large. The institutional expression for the superiority of Ottoman legality was the position of head lawyer of the entire empire-şeyhülislam in Turkish-who provided the final standpoint regarding various legal queries. Furthermore, his legal opinions (fetva in Turkish) carried heavy weight in legal courts along the vast domains of the empire. Through the sixteenth and the seventeenth centuries, the various şeyhülislams were incessantly occupied with codification projects that were formed in the sultanic court, dealt with various domains of the law, and were later copied and sent from the capital city of Istanbul to other major cities of the empire and even further to its periphery. The Ottoman Empire fashioned the work of courts of law and professional judges (kadis). The resolution of violent cases was increasingly considered a matter of the state/empire, involving official agents of police, and initiation of legal procedings against offenders, instead of being left at the discretion and handling of individuals and families who fell victim to violent crimes. Official state propaganda presented justice, law enforcement, and peace as fundamental components of the legitimacy of sultanic rule, especially during the era of Süleiman.

30 Colin Imber, The Ottoman Empire 1300-1650: The Structure of Power (London, 2002), 248-9: "The notion of a specific 'Ottoman Law' owes its origin to Bayezid II. It was he who, shortly before 1500 , issued a command to an anonymous official to compile in a bound volume '.. . all the Ottoman customary laws ...'. The result of the command was the law-book of $1499 \ldots$ The collection was a success, existing today in tens of copies, and going through several recensions until it reached its final form in about 1540 . It provided, for the first time, a universally applicable law and a source of reference for defining 'Ottoman Law'." 
Law in the European context had a different history, since legal science was related to Roman tradition (pre-dating Christian history) and to nonsanctified texts, such as the codes of Justinian and Theodosius. The urgent task of generations of medieval glossators (glossatores) of these texts was to create a coherent and rational—rational in medieval terms — architectural structure. The reading of the massive and often incoherent statements of the Justinian corpus through the tools of Aristotelian dialectics and logic (after the discovery of these writings in Europe during the late twelfth century) led to the formulation of sharp jurisprudential concepts and terminology. Here lay the great benefit and popularity of the jus civilis, which justified long years of hard university studies. Following Manlio Bellomo, the legal literature produced at the University of Bologna and elsewhere provided the conceptual tools, specific terminology, and jurisprudential argumentation that every professional of law, of whatever rank, would utilize, in almost every European context. ${ }^{31}$

The medieval legal tradition encountered severe criticism during the fifteenth century and throughout the early modern period..$^{32}$ To start with, the Italian humanists rejected the fundamental supposition that human law was required to imitate divine law. They offered a legal ethos diametrically opposed to the medieval one, founded on universal justice and politically expressed by one rule (the emperor), over all Christianity (see, for instance, Dante's De monarchia). With the denial of the divine ethos of human law, a new motivation was established-the consolidation of centralized states in Europe. One of the crucial components of state political machinery-alongside standing bureaucracy, increased armies, enforced order by police, a new schooling system, and a revenue apparatus - were the production of law and the compilation of existing local laws in broader codes, as signs of power and sovereignty. The law, under such a perspective, should be derived from "national" and ethnic traditions and not from Roman heritage. Contemporary needs (the legal terminology was lex odierna) and ethnic heritage were considered sources or roots of modern law, composed in national languages rather than in Latin. The need for clarity and lucidity appeared to be urgent, in order to make law present and active in larger parts of the population. It became more critical and disapproving of massive books of

31 Manlio Bellomo, The Common Legal Past of Europe, 1000-180o, trans. Lydia G. Cochrane (Washington, DC, 1995).

32 Italo Birocchi, Alla ricerca dell'ordine: Fonti e cultura giuridica nell'età moderna (Milan, 2002), exposes the increasing interest in teaching contemporary law and "national law." In such a context, the Canonic law lost much of its prestige and roles in favor of the utilitarian tools of the jus comune as a basis for state law. 
theoretical writing, and leaned toward legal compendia and shortened versions of law books. ${ }^{33}$

Centralized states, such as France, England, and Spain (and later the Netherlands and imperial Germany), were constantly occupied with collecting and sorting the various legal sources-issued by cities, guilds, and regions, as parliamentary decisions, court instructions, regal decrees, and exemptions, and in private collections-in order to document them in a more systematic and organized frame. This process of documenting legislation in writing traced back to thirteenth-century Italian cities. The difference lay in the extent of the geographical area of the early modern process, but even more in the intention to offer a consistent and more systematic perspective of this vast legal material. The late sixteenth century and the seventeenth witnessed the appearance of codes, first in Portugal (Ordenações afonsinas, 1467; Ordenações manuelinas, printed 1512), and later in France (collections of coutumiers in shortened and harmonized versions, the project of Antoine Loisel), in imperial Germany (the Carolina of Charles V), and in Spain (Leyes de Montalvo, the edict of Philip II regarding the criminal law)..$^{34}$ Padoa-Schioppa persuasively describes how the state moved from putting limits on local/particular laws to a phase of producing the law, and presenting itself as the source of law and legality, a source from which all other legal traditions of corporate bodies were derived. It took the place of God as a source of justice, and legitimized positive law on relativist and lay or national grounds, serving community and political utility. ${ }^{35}$

Rabbi Joseph Karo (1488-1575) lived in between the Spanish Catholic, Ottoman, and Jewish cultures. ${ }^{36}$ His family lived in Spain for several generations, and were forced to leave during the general 1492 expulsion. Karo is one of the most emblematic representatives of the Sephardi heritage, ${ }^{37}$ and carrier of its legal Halakhic tradition, disseminated later in the entire Mediterranean basin.

33 For current critique of overwriting in the legal field see António Manuel Botelho Hespanha, "Cultura giuridica, libri dei giuristi e techniche tipografiche," in Maria Antonietta Visceglia, ed., Le radici storiche dell'Europa: L'età moderna (Rome, 2007), 39-68; Birocchi, Alla ricerca dell'ordine, $159-65$.

34 Antonio Padoa-Schioppa, Storia del diritto in Europa: Dal medioevo all'età contemporanea (Milano, 2007); Birocchi, Alla ricerca dell'ordine, passim.

35 Padoa-Schioppa, Storia del diritto in Europa, 159-65.

36 Mor Altshuler, Chayei Maran Yosef Karo (The Life of Rabbi Yoseph Karo) (Tel-Aviv, 2016); Meir Benayahu, Yosef Bechiri: Maran Rabbi Yosef Karo (Joseph My Chosen One: Rabbi Joseph Karo) (Jerusalem, 1991); R. J. Zwi Werblowsky, Joseph Karo: Lawyer and Mystic (Philadelphia, 1980).

37 Yehuda D. Galinsky, “Arba'a Turim veHasifrut haHilchatit shel Sefard baMe'ah haArbaEsreh: Aspectim Historiim, Sifrutiim veHilchatiim" (The Four Turim and the Halakhic Literature of the 14th-Century Spain) (Ph.D. thesis, Bar-Ilan University, Ramat-Gan, 1999); Yoel Marciano, "Chachamim beSefard baMe'ah haChameshEsreh: 
The Sephardi Talmudic tradition he followed, as did some of the leading Sephardi rabbis of his generation, was inspired by the Talmudic methodology of Rabbi Isaac Canpanton, the "Eminent of Castile" (1360-1463). Canpanton implicitly adopted the Christian scholastics in his teachings. Besides, legal practice in Sephardi Jewish communities was profoundly influenced by local city regulations (fueros), as testified in rabbinic literature and non-Jewish legal testimonies. ${ }^{38}$ The Spanish Halakhic tradition in the early modern period had deep roots in pre-exile scholarship. Yet in the early modern period, due to new cultural and political encounters, it was confronted with a further context, i.e. the Ottoman Empire and its particular legal tradition. Rabbi Karo's younger years were spent in the western part of the Ottoman Empire, and later as an adult and mature juridical expert he moved to the city of Safed. During these years and in his sojourn in some cities, like in Rumeli (the western "Christian" part of the Ottoman Empire) and in the Bilad a-Sham ("Great Syria," since Safed was subordinated administratively and economically to Damascus), he composed his double codes of law: the long version called the Beit-Yosef (The House of Joseph), and the abridged one or the Shulchan-'Aruch (A Well-Set Table). In his biography, Karo incorporated the large cultural horizons of the Jewish Diaspora, especially the Iberian, in between the European zone-both Catholic and Protestant—and the Ottoman Empire. At the same time it marked a clear shift of the center of gravity from the European to the Ottoman Empire, as mentioned previously. One definite indication is the fact that along with his juridical expertise and high position, Rabbi Karo was an active mystic, documenting his incessant divine revelations in a mystical diary, "The Righteous Revealer" (Meghid Meisharim). The interaction between legal expertise and active mysticism is hardly known in the European contextcertainly not with respect to jurists of this caliber-but is fairly well known in the Ottoman Empire. ${ }^{39}$ Rabbi Karo's legal horizon, his double codes of law, teaching activities, and occupation as a judge in a court of law interacted profoundly with his European background, and mainly with his Ottoman surroundings.

Rabbinic literature, down the centuries, has been notoriously devoid of personal and individual testimonies (nowadays labeled "ego documents"). Luckily, in the case of Rabbi Karo, two texts testify to his personal and professional

Chinucham, Limudam, Yetziratam, Ma'amdam uDmutam" (The Jewish Sages in Fifteenth-Century Spain: Their Education, Social Status, Religious and Intellectual Profile) (Ph.D thesis, Hebrew University of Jerusalem, Jerusalem, 2009). Both these theses contain vast bibliographical references.

38 Fernando Suárez Bilbao, El fuero judiego en la España cristiana.| Las fuentes juridicas siglos $V-X V$ (Madrid, 2000).

39 On this phenomenon in the Islamic - and especially the Ottoman — context see Matthew B. Ignalls, "Subtle Innovations within Networks of Conventions: The Life, Thought, and Intellectual Legacy of Zakariyya al-Ansari (d. 1520)” (Ph.D. thesis, Yale University, 2011). 
motivations - on the course of his life in general, and in composing his codes of law in particular. The first is the aforementioned mystical diary, where he wove the events of his life and his personal thoughts among mystical revelations. The second is his introduction to Beit-Yosef, which Karo persistently typed several times, in various printed versions of this code, and to Shulchan-'Aruch. It is a sort of legal credo, aimed at legitimizing the canonization project.

Both codes, and especially the Shulchan-'Aruch, received an enthusiastic welcome among Jewish scholars, and later among the public at large. With its accompanying assertions or glosses of the Ashkenazi rabbi Moses Isserles (153072), they soon became a Halakhic canon, attracting various commentaries down the centuries. Karo insisted on fusing the major currents of Jewish Halakhah, mainly the Sephardi and the Ashkenazi, to an unprecedented extent. Significantly, ever since the sixteenth century, the double codes of Rabbi Karo have remained unsubstituted by another or similar code of law.

The production of Shulchan-'Aruch - by virtue of being the abridged, more accessible, and more popular code-is a watershed event in the history of Jewish religious tradition and primarily in its legalistic conceptions. As stated explicitly in the introduction to Beit-Yosef, its aim was to define Jewish collective identity and religious past as predominantly derived from the law. The constitutive act of conferring the Torah-a multivalent and condensed keyword in Jewish tradition, essentially comprising the entirety of Jewish lore-by Moses on Mount Sinai (Exodus 19-20), during the great divine revelation in front of the entire collective, is presented as an act restricted to legal instructions and juridical hermeneutic tools for future discussion and innovation by religious scholars. This sacred scene at Mount Sinai constitutes, according to Rabbi Karo, the infusion of Godly revelation (shekhinah, mishnah in Hebrew), the law (Halakhah), and the ethnic collective (ummah or 'am-Israel in Hebrew). This triple affiliation between religious fidelity, collective identity (the premodern nation), and legal codification (alongside increasing enforcement and state intervention in individual lives) is well known in both European states and empires (see, for instance, the Spanish monarchy and the Holy Roman Empire in the sixteenth century) as well as in the Ottoman Empire, as mentioned previously. ${ }^{40}$

Karo's mystical diary discloses how deeply his legalistic project was related to the reformation and regeneration of Jewish religion and religious life. ${ }^{41}$ This was not exceptional in a period when European rulers, Ottoman sultans (especially

40 Krstić, "Illuminated by the Light of Islam" 35-63; Terzioglu, "How to Conceptualize Ottoman Sunnitization," 301-38; Terzioglu, "Where 'Ilm-i Häl Meets Catechism," 79-114. ${ }^{41}$ Roni Weinstein, "Kabbalaha, Halakhah, and Ritual," in Weinstein, Kabbalah and Jewish Modernity, 67-82. In this chapter, as well as in others, I have claimed that early modern Kabbalists in Safed aimed at a comprehensive reform of religious life. 
Süleiman, following the analysis of Cornell Fleischer), and Safavid shahs mobilized law and legislation with wider apocalyptic visions, and considered the renovation of religion a major component of their messianic plans..$^{42}$ Yet in his grand vision, Rabbi Karo was closer to the Ottoman context. In constructing his own image as a leading agent of reformative change and assertive action in Jewish history, he perceived himself as ideally fulfilling the role of a Jewish şeyhülislam. The angelic maggid revealed to Karo in one of his messages in the years 1542-3, "I will uplift you to a position of leader and nagid over the entire Jewish Diaspora in the kingdoms of Arabistan $[s i c] \ldots$ and through you I would renovate the rabbinic Ordination, and I would grant you the privilege to terminate your books, and then you would commit martyrdom for the sake of my holy name." 43 To start with, he would not only become a leader (sar in the original) but also acquire the title nagid, which for centuries served as the official designation of the leaders of Egyptian Jewry and beyond, including the dynasty founded by Maimonides several centuries earlier. Ever since the Fatimid period, the leader of the Jews in Egypt possessed legal and political authority over the Holy Land Jews (including the cities of Jerusalem and Safed). After the conquest of Mameluke Egypt by the Ottomans (1516), the role of nagid was discontinued, which left a religious and political vacuum, which Rabbi Karo wished to reverse and insert himself in. ${ }^{44}$ The disruption of previous equilibrium as a cause of shifting a religious and political authority (from Cairo to Safed) echoed the rise of the Ottoman Empire and its capital city, Istanbul, following the Mongol invasions of the Arab world.

In Karo's vision, the intended geographical zone for his new court of law, subject to his judicial authority, expanded to the entire Jewish ecumene. The oriental part was termed "Arabistan," a word of Persian (and not Arabic, Aramaic, or Hebrew) origins. The Persian language, along with Turkish and Arabic, was one of the threefold linguistic requirement in the cultural baggage of members of the Turkish elite at this period. The legal guild, forming in the sixteenth century around the courts of sultans in Istanbul and in major cities, was one of the backbones of Ottoman rule, alongside the military, bureaucratic, and erudite elites. Not by coincidence, Rabbi Karo was involved in a (failed) attempt to renovate the official ordination (semichah in Hebrew) to rabbinic profession. This affair, causing sharp polemics among rabbis in Safed and Jerusalem in the

42 Sanjay Subrahmanyam, "Connected Histories: Notes towards a Reconfiguration of Early Modern Eurasia,” Modern Asian Studies 31/3 (1997) (special issue: The Eurasian Context of the Early Modern History of Mainland South-East Asia, 1400-180o), 735-62; Fleischer, "The Lawgiver as Messiah"; Matt Goldish, The Sabbatean Prophets (Cambridge, MA, 2004); Krstić, Contested Conversions to Islam, passim.

43 Joseph Karo, Megid Meisharim (Vilnius, 1880), 21b, 29c.

44 This was noted by Altshuler, The Life of Rabbi Yoseph Karo, 265-7. 
mid-sixteenth century, could not produce concrete consequences for rabbinic functioning and autonomy, since the Ottomans set clear limits to the autonomy granted to Jewish communities. It marked the awareness of Jewish scholars of the importance of professionalization and the institutionalization of the legal guild in the Ottoman context, and their attempt to adopt similar patterns. The books mentioned (chiburim) in Karo's revelation refer directly to his magna opera of both codes - as the law in writing - benefiting from the recent privilege of international circulation of printed books. The element of martyrdom clearly discloses the pietistic elements of his vision, and the wish to compete with other religious traditions. ${ }^{45}$

Unlike any other contemporary rabbi (or, for that matter, previous or future ones), Karo soon acquired the title "Our Master" (maran in Aramaic): not a typical label in the rabbinic context. If it was rather out of context in the Jewish tradition, it sounded more familiar in the Ottoman context, where the formal designation of the chief legal personality was şeyhülislam, literally "Thy Master/Authority of Entire Islam." This title had roots in Mameluke tradition, reserved for the heads of the four leading legal schools. Yet in the sixteenthcentury Ottoman context, it became part of the state apparatus, with increased authority to enforce legal positions and enhance state legislation. ${ }^{46}$ The title of maran befittingly reflected the self-construction of Rabbi Karo, as revealed in his diary and in his practical activities as a scholar and judge. He considered himself (and his double magnum opus) the culmination of the entire Jewish erudition in the legal Halakhic domain. ${ }^{47}$ His work offers a stage of encounter for-and between-all present and past scholars. This encounter is not to be taken symbolically (as an "as-if" encounter), but as a very real one, since these discussions are held in a heavenly school, where all the dead scholars of the past-especially Karo himself - participate in the same debate during moments of mystical eruption, along with contemporary ones.

Jewish scholars of the Halakhah (Talmidei chachamim, rabbis, decisors/ poskim), as is evident, form a distinct social and professional guild, transcending constraints of time. Rabbi Karo's work reflects the summation and clarification of this heritage in a double sense: the detailed version of Beit-Yosef is primarily meant for the edification of professional scholars, while the abridged Shulchan'Aruch is for the general Jewish population as well. It offers, as the official Ottoman kanunames of the sixteenth and seventeenth centuries did, a general law applicable beyond the local diversity of various diasporas. Thinking of a precedent for

45 On the discussion of martyrdom in the Mediterranean context, beyond the Christian context, see Krstić, Contested Conversions to Islam, index s.v. "Martyrdom."

46 Burak, The Second Formation of Islamic Law, 21-64.

47 See the extended discussion in Altshuler, The Life of Rabbi Yoseph Karo, passim. 
such a grandiose project, Karo explicitly referred to the official and supreme institution of Sanhedrin in his various writings, which functioned during the Second Temple period, and even later after the temple's destruction. This sacred institution provided an antecedent and a model: as a supreme institution for reaching a legal consensus, inspired by divine guidance. These mechanisms were shifted and reelaborated in Karo's mind, when he proposed ways of overcoming legalistic disagreement by favoring one centralistic focus of consensus authorized by his legal codes. Similar to his combination of past Jewish traditions and contemporary Ottoman reality is his treatment of internal hierarchy among legal scholars. In his introduction, he presents a lucid list of various scholars and their relative ranks. There are rudimentary precedents of a similar approach in rabbinic literature in post-Talmudic periods, but certainly not to the extent that Karo demonstrates. Again, it echoes the important role of tabaqat literatureengaged in the transmission of legal heritage, especially until its endpoint in the Ottoman present, and the dominant role of the Hanafi school (madhhab) - and the relative role and prestige of every individual scholar within this chain of transmission. ${ }^{48}$

Rabbi Karo made concrete efforts to implement his vision. He established a court of law and encouraged nonlocal communities to send their legal cases to him instead of using the local legal process. Safed was to function as a center for the entire Jewish people, and his court as a kind of international court of law. Further, he established five religious schools in Safed, and attempted to enlarge the basis of legal activity. His students were mostly stationed in positions of influence. He was one of the first scholars to compose their major works with awareness and recognition of the advantages that the new print revolution offered, rather than having to disseminate tracts through manuscripts. The Shulchan-'Aruch was sent for printing in Italy, the Jewish center of printing and distribution of books, rather than to a local Jewish/Ottoman printing press. But despite the magnitude of his efforts, Karo was a private person, with no substantial institutional support behind him. Like other rabbinic figures of rank, he could address the people who accepted his authority, mainly among the Sephardi residents of Safed. At his disposal there were no political means and no executive structure, like a police force, or organizational resources to impose his authority or legal instructions. Additionally, the volition-based character of Jewish communities, and their limited capacity to enforce Jewish law in general, hindered the implementation of Karo's legalistic vision. Also, there were the decades-long disputes with the other towering legal authority in Safed-Rabbi Moses of Trani-which obstructed the implementation of Karo's grand vision of one law to the entire Jewish Diaspora.

48 Burak, The Second Formation of Islamic Law, 65-100. 
Yet, regardless of these limitations, the global perspective is still relevant in measuring and analyzing his life project. It places the Jewish case study next to other religious minorities within the Ottoman Empire, sharing the same problematic of aspired autonomy and concrete limitations. Functioning in Safed, the periphery of the Ottoman hard core of the Anatolia and Rumeli areas, the carriers of local traditions insisted on maintaining their autonomy, in spite of competing with centralistic pressures. The cases of Arab legal traditions in Syria and those in Egypt under Ottoman rule demonstrate how persistent they stood before Ottoman centralism, and the need for a long negotiation process between the periphery and the center. ${ }^{49}$ Karo's horizons fitted such an interstice between a centralistic strategy of Ottoman officials in the Bilad a-Sham, and the adoption of its innovative aspects of Ottoman legality in a Jewish context. It was a vision marking the direction of its future advancement, even though its present implementation was limited. It put forth the law-beside the new Kabbalistic theology —as the cornerstone of collective identity, and rigidly defined the limits of this law in his double codes. Most importantly, his monumental legal project aimed at providing the entire Jewish ecumene with a unified legal reference. Even though it could not be imposed beyond the Sephardi community, the vision it suggested was entirely global: the Jewish law/Halakhah indeed needed to respond to changes taking place in both Europe and the Ottoman Empire in order to remain relevant.

49 Jane Hathaway, The Politics of Households in Ottoman Egypt: The Rise of the Qazdaglis (Cambridge, 1997); Michael Winter, "Ottoman Kadis in Damascus in the 16th-18th Centuries," in Ron Shaham, ed., Law, Custom, and Statute in the Muslim World: Studies in Honor of Aharon Layish (Leiden, 2006), 87-109; Burak, The Second Formation of Islamic Law, 163-223. 